\title{
Instrumentation of Flow-Through USP IV Dissolution Apparatus to Assess Poorly Soluble Basic Drug Products: a Technical Note
}

\author{
Alice Paprskářová, ${ }^{1}$ Petra Možná, ${ }^{1}$ Enoche F. Oga, ${ }^{1}$ Abdelbary Elhissi, ${ }^{1,2}$ and Mohamed A. Alhnan ${ }^{1,3}$
}

Received 20 July 2015; accepted 19 October 2015; published online 16 November 2015

\begin{abstract}
Supersaturation and precipitation are common limitations encountered especially with poorly soluble basic drugs. The aims of this work were to explore the pattern of dissolution and precipitation of poorly soluble basic drugs using a United States Pharmacopoeia (USP) IV dissolution apparatus and to compare it to the widely used USP II dissolution apparatus. In order to investigate the influence of gastric emptying time on bioavailability, tables of two model drugs (dipyridamole $100 \mathrm{mg}$ and cinnarizine $15 \mathrm{mg}$ ) were investigated and $\mathrm{pH}$ change from 1.2 to 6.8 were achieved after 10, 20 or 30 min using USP II or USP IV dissolution apparatuses. Using USP II, dipyridamole and cinnarizine concentrations dropped instantly as a result of drug precipitation with drug crystals evident in the dissolution vessel. At $\mathrm{pH}$ change times of 10, 20 and $30 \mathrm{~min}$, the total amount of dissolved drug was dependent on $\mathrm{pH}$ change time. Using USP IV, at a flow rate of $8 \mathrm{ml} / \mathrm{min}$, it was possible to have comparable release to agitation at $50 \mathrm{rpm}$ using USP II suggesting that comparable hydrodynamic forces are possible. No drop in drug percentage occurs as the dissolved fraction was readily emptied from the flow cell, preventing drug accumulation in the dissolution medium. However, a negligible percentage of drug release took place following $\mathrm{pH}$ change. In conclusion, the use of the flow-through cell dissolution provided laminar flow, use of realistic fluid volumes and avoided precipitation of dissolved drug fraction in the gastric phase as it is discharged before $\mathrm{pH}$ change.
\end{abstract}

KEY WORDS: USP 4; USP 2; Flow-through; Antihistamine; Anticoagulant; Gastric emptying.

\section{INTRODUCTION}

pH-dependent solubility is a major consideration for poorly soluble basic drugs, whose solubility is significantly reduced upon gastric emptying (1). This leads to supersaturation, which may be followed by precipitation of the basic drug in intestinal fluids where it is likely to be absorbed. This can result in erratic bioavailability and variable onset of action following oral administration (2). For instance, an elevated gastric $\mathrm{pH}$ has led to a slower and compromised oral bioavailability of dipyridamole with less than half $C_{\max }$ and $T_{\max }$ observed (3). In another report, the oral bioavailability of ketoconazole, a poorly soluble basic drug, was significantly compromised in achlorhydric patients (4).

Several dissolution models have been proposed to simulate changes in dissolution that occur following gastric emptying. One study has reported the use of a 96-well microtiter plate to study drug precipitation in different simulated GI fluids (5). Also, a United States Pharmacopoeia (USP) dissolution test with single medium for each test has been utilised (6). Despite the merits of these methods, they do not describe the changes in $\mathrm{pH}$ that occur following gastric emptying. The USP has also described a $\mathrm{pH}$ change method utilising the USP II apparatus that has been

\footnotetext{
${ }^{1}$ School of Pharmacy and Biomedical Sciences, University of Central Lancashire, Preston, Lancashire PR1 2HE, UK.

${ }^{2}$ College of Pharmacy, Qatar University, P.O. Box 2713, Doha, Qatar.

${ }^{3}$ To whom correspondence should be addressed. (e-mail: malbedalhnan@uclan.ac.uk)
}

applied to dosage forms (2,7). Mathias et al. suggested a twostage micro-dissolution method using a low-volume compartment by dissolving the drug in simulated gastric fluid (SGF) for 20 min followed by the addition of fasted state simulated intestinal fluid (FASSIF) (8). A general concern about these methods is the possible overestimation of drug precipitation, since these systems do not simulate the absorption step $(9,10)$.

One approach towards overcoming this is to use multicompartments where gastric and basic chambers are connected with tubing and the speed of gastric emptying is simulated by changes in flow rate (11-13). Although this approach is increasingly receiving attention, its tailored nature makes it difficult to validate and reproduce.

The USP IV is a well-established standardised flow-through dissolution system that has also been extensively used to assess the drug release pattern from extended-release formulations (14-16). It has also been increasingly used to study release pattern from microsphere and film-based systems (17-19). It allows laminar flow, use of different sequences of dissolution media and continuous replenishing of drug saturated media with a fresh drug-free medium, hence limiting the risk of supersaturation. Despite these advantages of using the USP IV apparatus, little information is available on its use for mimicking the in vivo dissolution of poorly soluble basic drugs.

The aims of this work were to explore the pattern of dissolution and precipitation for poorly soluble basic drugs using the USP IV dissolution apparatus and to compare it to the widely used USP II dissolution apparatus. 


\section{MATERIALS AND METHODS}

\section{Materials}

A brand of dipyridamole tablets $100 \mathrm{mg}$ (Persantine ${ }^{\circledR}$, Boehringer Ingelheim, UK) and $15 \mathrm{mg}$ cinnarizine tablets (Stugeron ${ }^{\circledR}$, Janssen-Cilag Ltd., UK) were purchased from local pharmacies. Dipyridamole and cinnarizine standards were purchased from Sigma-Aldrich, UK. All other chemicals were commercially available and of analytical grade.

\section{pH Change Dissolution Test Using the USP II Apparatus}

Immediate-release tablets are likely to disintegrate within minutes in the stomach (20) and the disintegrated and dissolved parts will empty in the fasted state in a mono-exponential pattern (21) with a gastric emptying time for calorie-free liquids of less than $30 \mathrm{~min}(22,23)$. In order to simulate different gastric emptying times, three different $\mathrm{pH}$ change systems were utilised with an emptying time of 10,20 or $30 \mathrm{~min}$. The USP II paddle apparatus (Erweka ${ }^{\circledR}$ DT700LH dissolution system, Heusenstamm, Germany) was employed to assess the tablet dissolution profiles. One tablet was placed in a vessel containing $750 \mathrm{ml}$ of $0.1 \mathrm{M} \mathrm{HCl}$ as a dissolution medium at $37^{\circ} \mathrm{C} \pm 0.5^{\circ} \mathrm{C}$. After 10,20 or $30 \mathrm{~min}, 250 \mathrm{ml}$ of $0.215 \mathrm{M}$ tri-sodium phosphate (maintained at $37^{\circ} \mathrm{C} \pm 0.5^{\circ} \mathrm{C}$ ) was added to the dissolution vessel, and the $\mathrm{pH}$ of the solution was adjusted to $6.8 \pm 0.05$ when necessary using $3 \mathrm{~N} \mathrm{HCl}$ or $3 \mathrm{~N} \mathrm{NaOH}$ solutions. Following this, the dissolution experiment was continued for another 50,40 or $30 \mathrm{~min}$, respectively. The total time per run was $60 \mathrm{~min}$, during which samples were collected every $3 \mathrm{~min}$ for the first $30 \mathrm{~min}$ and then every $5 \mathrm{~min}$. The speed of the paddle was set at $50 \mathrm{rpm}$ and each dissolution test was replicated three times. These were filtered and then measured by inline UV spectrophotometer (Automated Lab SP700, UK) at $\lambda_{\max }$ of 282 and $254 \mathrm{~nm}$ for dipyridamole and cinnarizine, respectively. Data was processed using Icalis software (Icalis Data Systems Ltd, Berkshire, UK). A standard calibration curve was prepared for each drug in acidic and buffer media and the limit of detection for both drug molecules was $2 \mathrm{mg} / \mathrm{l}$. The percentage of released drug was calculated based on the amount of detected drug at each time point in comparison to the labelled dose.

\section{pH Change Dissolution Test Using the USP IV Apparatus}

In order to obtain comparable results following $\mathrm{pH}$ change between the USP II and USP IV, the same dissolution medium used in the gastric phase of the USP II has been utilised. Phosphate buffer ( $\mathrm{pH}$ 6.8) was prepared as a 3:1v/v mixture of hydrochloric acid $(0.1 \mathrm{M})$ and phosphate buffer (0.215 M), adjusted to $\mathrm{pH} 6.8$.

A USP IV Apparatus (Sotax CE7 Smart, Switzerland), connected to a SOTAX fraction collector, was equipped with $12-\mathrm{mm}$ cell size containing one 5-mm sphere and $1.86 \mathrm{~g}$ of glass beads $(1 \mathrm{~mm})$ to provide laminar flow. Each tablet was placed on the beads within the cell with $25 \mathrm{~mm}$ (FG/B) (Whatman, USA). The apparatus was used in an open-loop system, where new dissolution medium was continuously introduced into the system. The temperature of the water bath was set at $37^{\circ} \mathrm{C} \pm 0.5^{\circ} \mathrm{C}$ and the flow rate of media was set at $8 \mathrm{ml} / \mathrm{min}$. After 10,20 or $30 \mathrm{~min}$, the medium was switched from $\mathrm{HCl}$ to phosphate buffer to mimic different gastric emptying time with a total run time of $60 \mathrm{~min}$.

The samples obtained from the fraction collector were processed using a Jenway Spectrophotometer (Bibby Scientific Ltd, UK) for dipyridamole. In the case of poorly soluble cinnarizine and in order to ensure that all drug had been dissolved, the collected samples were diluted at 1:1 volume ratio with acetonitrile and analysed by HPLC. The concentration of dipyridamole and cinnarizine was assessed at $0,3,6,9,12,15,18$, $21,24,27,30,35,40,45,50,55$ and $60 \mathrm{~min}$. The percentage of released drug was calculated based on the amount of detected drug at each time point in comparison to the labelled dose.

\section{HPLC Analysis}

\section{Dipyridamole}

The amount of released dipyridamole was analysed on a HPLC system (Agilent Technologies 1200 series, Germany).
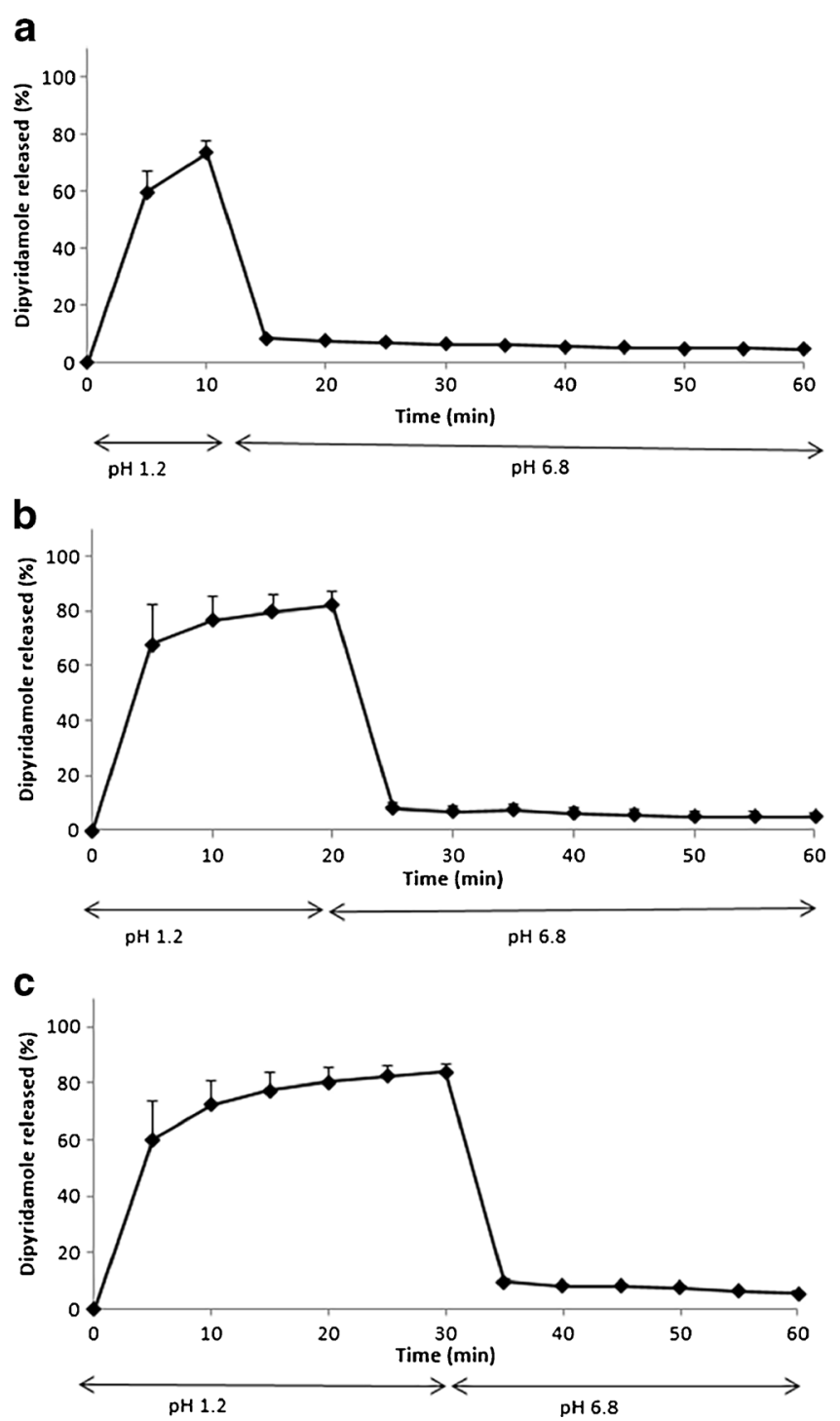

Fig. 1. In vitro release of dipyridamole from tablets using $\mathrm{pH}$ change in the USP II dissolution systems with change of $\mathrm{pH}$ a after $10 \mathrm{~min}, \mathbf{b}$ after $20 \mathrm{~min}$ and $\mathbf{c}$ after $30 \mathrm{~min}$ 


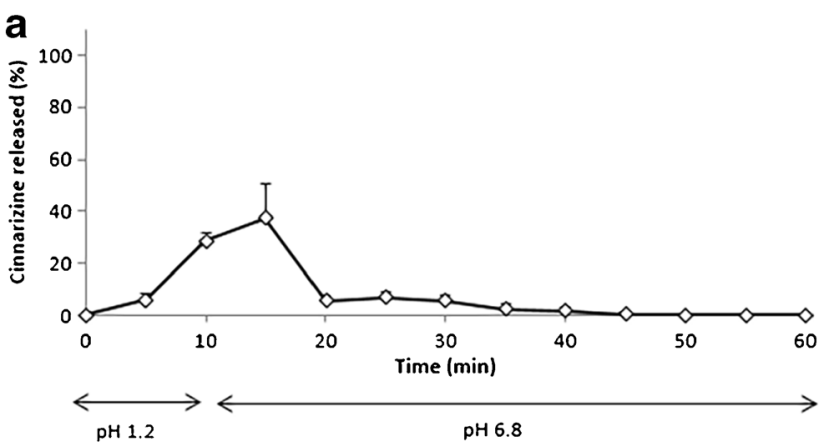

b
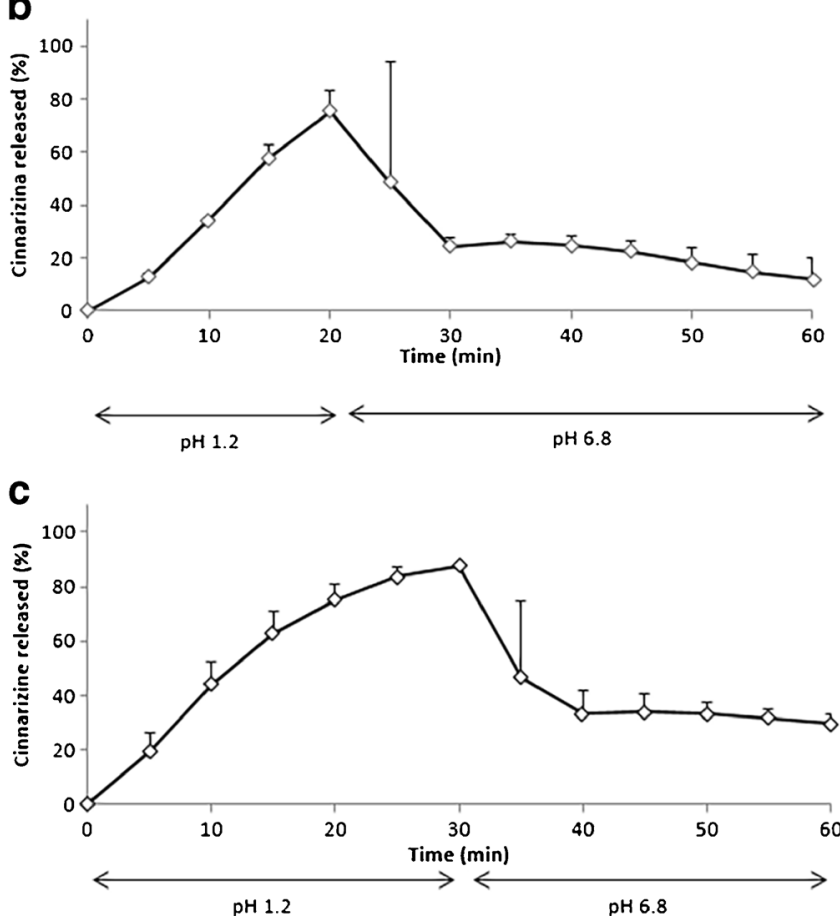

Fig. 2. In vitro release of cinnarizine from tablets using $\mathrm{pH}$ change in the USP II dissolution systems with change of $\mathrm{pH}$ a after $10 \mathrm{~min}, \mathbf{b}$ after $20 \mathrm{~min}$ and $\mathbf{c}$ after $30 \mathrm{~min}$

Each sample was dissolved in a medium containing surfactant before the injection of $10 \mu \mathrm{l}$ into the HPLC system. For the chromatographic conditions, the mobile phase comprised phosphate buffer $\mathrm{pH} 6.8$ and acetonitrile (50:50) at a flow rate of $1.5 \mathrm{ml} / \mathrm{min}$. The XTerra column (Waters Inc., Ireland) was of $4.6 \mu \mathrm{m} \mathrm{ID} \times 150 \mathrm{~mm}$ length with $185 \mu \mathrm{m}$ particle size. The

Table I. Percentage of Maximum Drug Release from Poorly WaterSoluble Basic Drug Tablets in USP II and IV pH Change Dissolution Tests

\begin{tabular}{|c|c|c|c|c|}
\hline \multirow[t]{2}{*}{$\mathrm{pH}$ change time $(\mathrm{min})$} & \multicolumn{2}{|c|}{$\begin{array}{l}\text { Dipyridamole } \\
\text { 100-mg tablet }\end{array}$} & \multicolumn{2}{|c|}{$\begin{array}{l}\text { Cinnarizine } \\
15-\mathrm{mg} \text { tablet }\end{array}$} \\
\hline & USP II & USP IV & USP II & USP IV \\
\hline 10 & 73.4 & 98.3 & 37.9 & 54.5 \\
\hline 20 & 81.8 & 100 & 75.4 & 82.7 \\
\hline 30 & 83.9 & 100 & 87.7 & 87.9 \\
\hline
\end{tabular}

USP United States Pharmacopoeia column temperature was maintained at $40^{\circ} \mathrm{C}$. Detection was performed using UV-visible spectrophotometry and the wavelength of detection was set at $285 \mathrm{~nm}$. A run time of 6 min was utilised and each sample was run in triplicates and the limit of detection was $0.5 \mathrm{mg} / \mathrm{l}$.

\section{Cinnarizine}

Samples were analysed using HPLC (Agilent Technologies 1200 series, Germany). A reversed-phase column (C18 Synergi Max-RP80, Phenomenex, USA) was used with dimensions $250 \mathrm{~mm} \times 4.60 \mathrm{~mm}$, particle size $4 \mu \mathrm{m}$. The mobile phase, which consisted of acetonitrile $(90 \% v / v)$ and $10 \mathrm{mM}$ ammonium acetate buffer $(10 \% v / v)$ adjusted to $\mathrm{pH} 7$ by ammonium hydroxide with distilled water (1:4), was eluted at a flow rate of $1.5 \mathrm{ml} / \mathrm{min}$. The injection volume was $20 \mu \mathrm{l}$, and a UV detector employed an excitation wavelength of $254 \mathrm{~nm}$. The temperature in the column was maintained at $30^{\circ} \mathrm{C}$ and the run time for each sample was $8 \mathrm{~min}$. Under these conditions, the retention time for cinnarizine was about $5.5 \mathrm{~min}$ and the limit of detection was $0.1 \mathrm{mg} / \mathrm{l}$. The assay was validated in
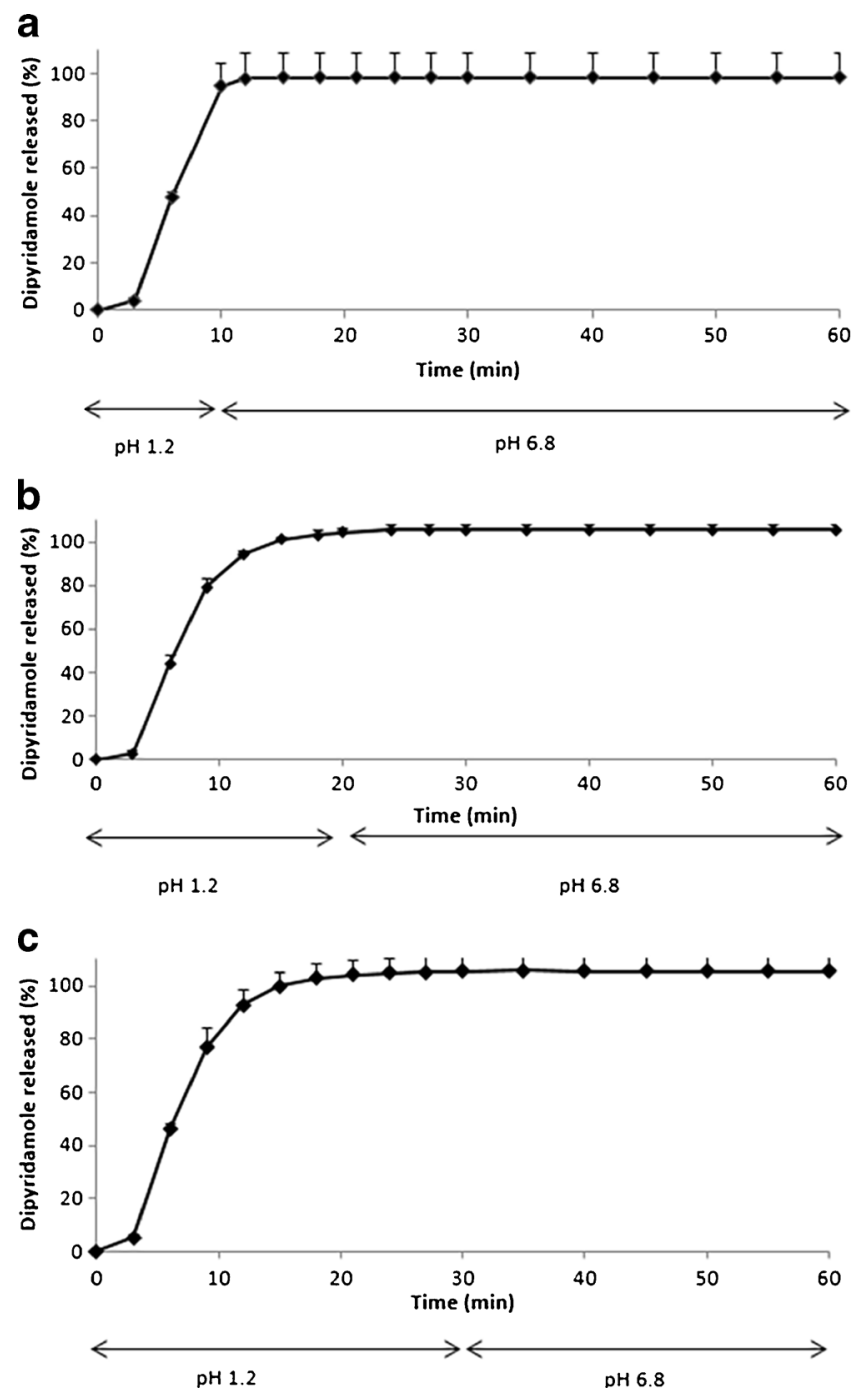

Fig. 3. In vitro release of dipyridamole from tablets using $\mathrm{pH}$ change in the USP IV dissolution systems (flow rate $8 \mathrm{ml} / \mathrm{min}$ ) with change of $\mathrm{pH}$ a after $10 \mathrm{~min}, \mathbf{b}$ after $20 \mathrm{~min}$ and $\mathbf{c}$ after $30 \mathrm{~min}$ 
terms of accuracy and precision using standard methodologies.

\section{RESULTS AND DISCUSSION}

The dissolution profile of dipyridamole immediate-release tablets on simulating a gastric emptying time of 10, 20 and $30 \mathrm{~min}$ in the USP II apparatus is illustrated in Fig. 1. For dipyridamole, more than $70 \%$ of the drug was released within $10 \mathrm{~min}$ for the various $\mathrm{pH}$ change times. However, the proportion of dissolved cinnarizine was mainly affected by the timing of gastric emptying (Fig. 2, Table I). This indicates the critical importance of gastric emptying times of these formulations.

Upon $\mathrm{pH}$ change, both cinnarizine and dipyridamole showed an instant drug-to-drug concentration in the USP II dissolution apparatus. Such a drop is directly related to the precipitation drug crystals within the dissolution vessel. As the $\mathrm{pH}$ of the media in the intestinal phase exceeds the $\mathrm{pKa}$ of both basic molecules (pKa 6.4 for dipyridamole (21) and $\mathrm{pKa}$

a

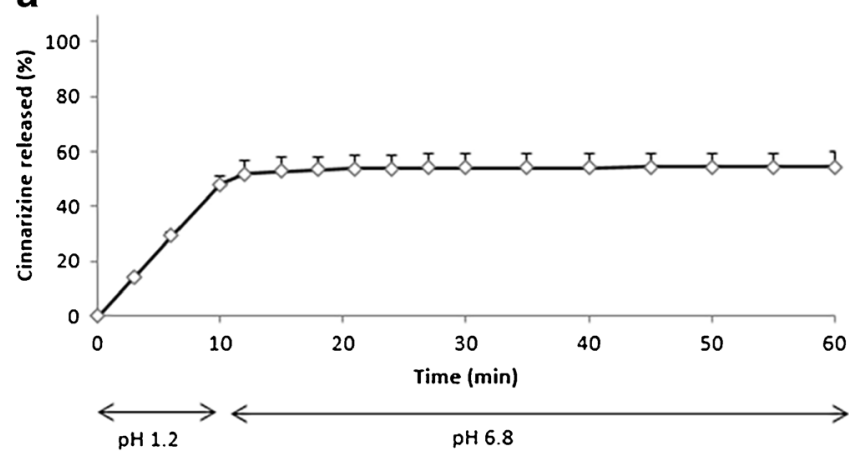

b

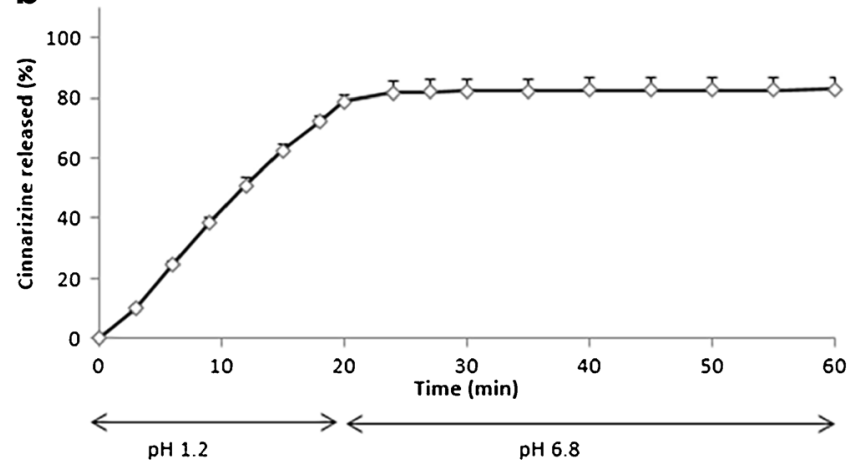

C

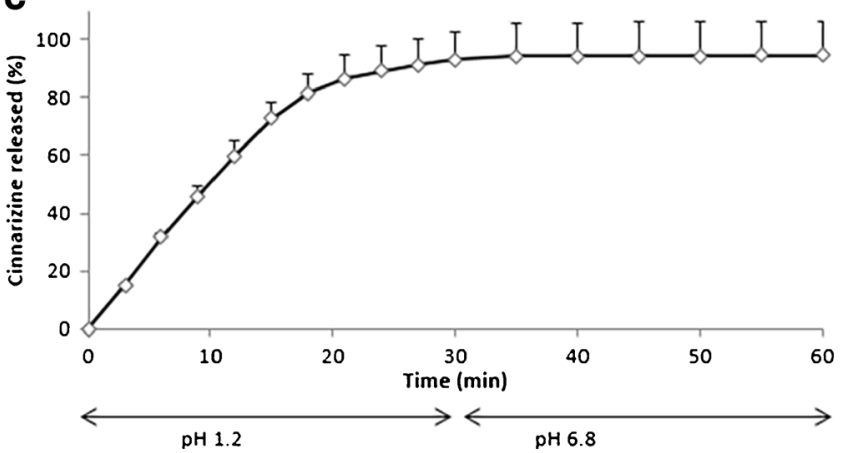

Fig. 4. In vitro release of cinnarizine using $\mathrm{pH}$ change in the USP IV dissolution systems (flow rate $8 \mathrm{ml} / \mathrm{min}$ ) with change of $\mathrm{pH}$ a after $10 \mathrm{~min}, \mathbf{b}$ after $20 \mathrm{~min}$ and $\mathbf{c}$ after $30 \mathrm{~min}$
1.94 for cinnarizine (24)), their solubility drops significantly (from $29,000 \mathrm{mg} / \mathrm{l}(25)$ to $6 \mathrm{mg} / \mathrm{l}$ at $\mathrm{pH} 6.8$ (26) for dipyridamole and from $2100 \mathrm{mg} / \mathrm{l}$ at $\mathrm{pH} 1.2$ (25) to $<2 \mathrm{mg} / \mathrm{l}$ at $\mathrm{pH} 6.8$ (2) for cinnarizine). This results in drug supersaturation in dissolution media followed by drug precipitation. It could also be related to the tablet composition, where solubility enhancer and/or precipitation inhibitor is often included in the additives of tablet formulation (11). However, such precipitation is unlikely to be realistic as basic drugs dissolve in gastric fluids and quickly emptied where they are mainly absorbed in the upper small intestine.

In order to assess the influence of in flow-through cell on drug release profile, a dissolution method using the dissolution media and $\mathrm{pH}$ change time were carried out using the USP IV. When flow rates of 2 and $4 \mathrm{ml} / \mathrm{min}$ were utilised, it was visually noticed that very slow disintegration took place and limited or no drug release was detected following $1 \mathrm{~h}$. This could be due to the weak disintegrating effect of flow-through cell in comparison to paddle-based dissolution tests (27). In flow-through systems, these agitation forces are mainly generated from the pulses of the peristaltic pump and they are likely to be minimal when a
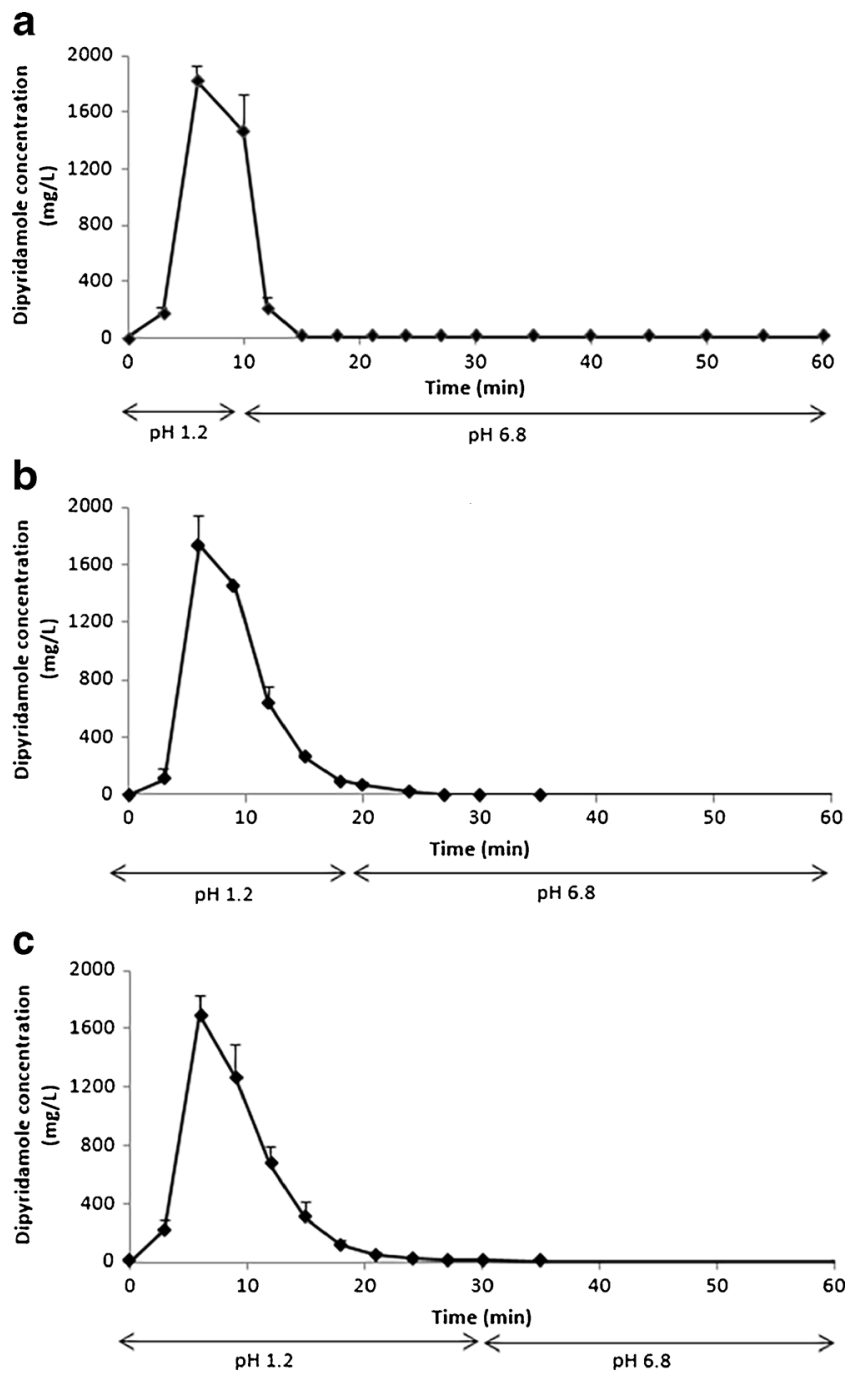

Fig. 5. Dipyridamole concentration-time plot for the USP IV flowthrough cell (flow rate $8 \mathrm{ml} / \mathrm{min}$ ) with change of $\mathrm{pH}$ a after $10 \mathrm{~min}, \mathbf{b}$ after $20 \mathrm{~min}$ and $\mathbf{c}$ after $30 \mathrm{~min}$ 

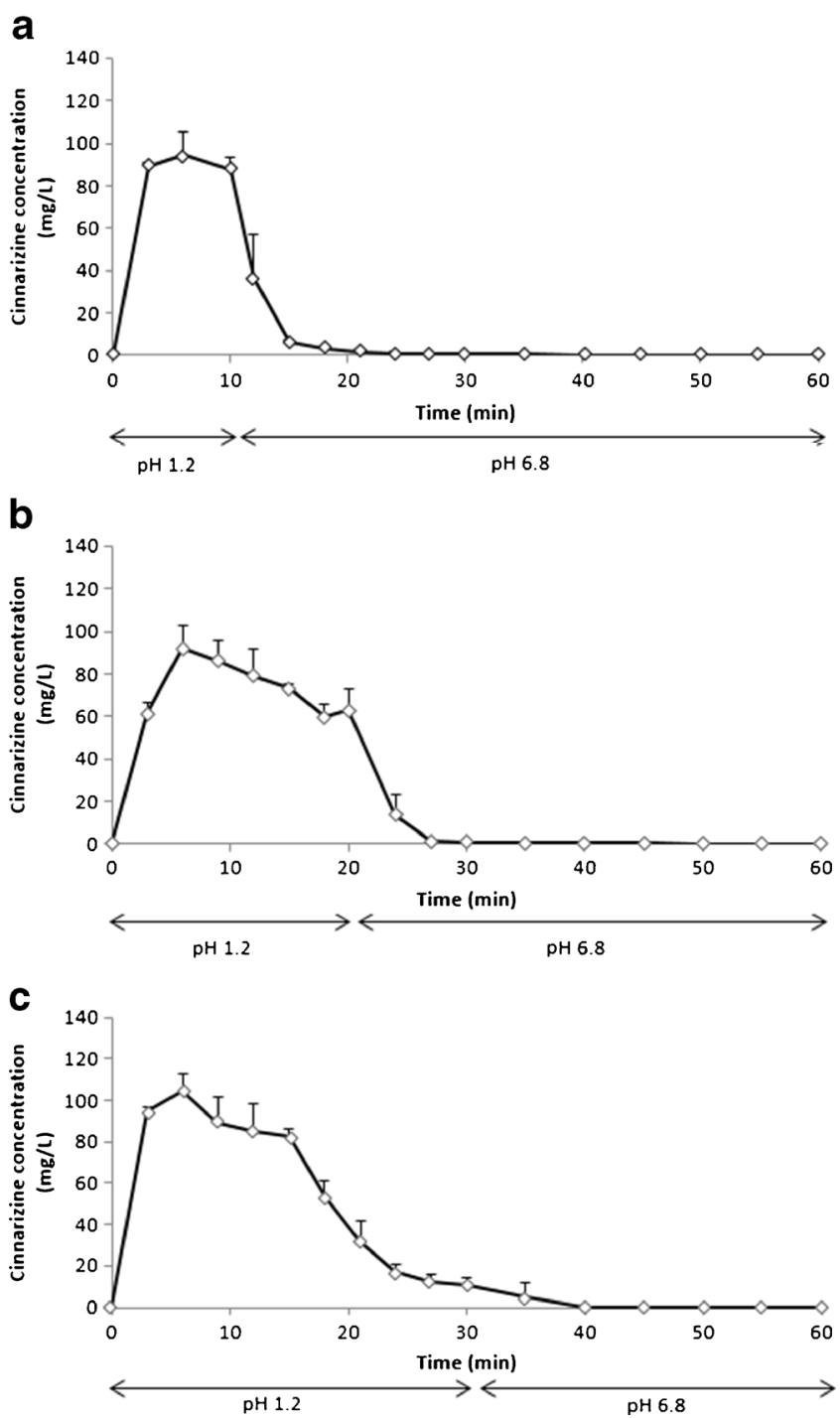

Fig. 6. Cinnarizine concentration-time plot for the USP IV flowthrough cell (flow rate $8 \mathrm{ml} / \mathrm{min}$ ) with change of $\mathrm{pH}$ a after $10 \mathrm{~min}$, b after $20 \mathrm{~min}$ and $\mathbf{c}$ after $30 \mathrm{~min}$

flow rate of 2 or $4 \mathrm{ml} / \mathrm{min}$ was applied. This is in contrast with USP disintegration tests for example where more major shear force is generated (28). However, at a flow rate of $8 \mathrm{ml} / \mathrm{min}$, it was possible to have a comparable release to $50 \mathrm{rpm}$ of paddlebased USP II dissolution (Figs. 3 and 4), suggesting that comparable hydrodynamic forces are possible to obtain at this flow rate (29). The majority of drug dissolution ( $>90 \%$ ) was achieved using a biologically realistic volume of gastric medium $(240 \mathrm{ml}$ after $30 \mathrm{~min}$ ).

The design of the flow-through dissolution cell allows laminar and more homogeneous flow to be readily achieved due to the pressure drop imparted when beads are used (18). No drop in drug percentage occurs as the dissolved fraction was readily emptied from the flow cell, preventing drug accumulation in the dissolution medium. The flow-through appeared to have significantly higher percentage of dissolved drug compared to paddle system using the realistic volume of gastric medium ( $240 \mathrm{ml}$ after $30 \mathrm{~min}$ ) composition (Table I).

Figures 5 and 6 illustrate the concentration of drugs within the flow-through cell in the USP IV apparatus. Unlike the USP II where the drug stays in the media after $\mathrm{pH}$ change, all dissolved drug is transferred from the flow-through cell in the USP IV; this will allow the assessment of dissolving drug fraction (if any) in the intestinal phase. However, only a limited amount of drug dissolved in the intestinal phase of the test. It is clear that most of the dissolution in the intestinal phase took place within the first few minutes after $\mathrm{pH}$ change. In the first few minutes after $\mathrm{pH}$ change, the flow-through cells are likely to contain a mixture of acidic and neutral buffer before it becomes completely dominated with intestinal medium ( $\mathrm{pH} \mathrm{6.8).} \mathrm{It} \mathrm{is} \mathrm{possible} \mathrm{that} \mathrm{some} \mathrm{drug} \mathrm{dissolved}$ in this medium before the increase in $\mathrm{pH}$ to the intestinal values.

\section{CONCLUSION}

Unlike paddle-based dissolution methods, the flow-through cell dissolution provided laminar flow, used realistic fluid volumes and avoided precipitation of dissolved drug fraction in the gastric phase as it is discharged before $\mathrm{pH}$ change. Using both dissolution systems, the percentages of dissolved drug at the end of the dissolution test was significantly influenced by the $\mathrm{pH}$ change time. Incomplete drug dissolution due to shorter residence time in the stomach may compromise oral bioavailability.

\section{REFERENCES}

1. Mou D, Chen H, Wan J, Xu H, Yang X. Potent dried drug nanosuspensions for oral bioavailability enhancement of poorly soluble drugs with $\mathrm{pH}$-dependent solubility. Int J Pharm. 2011;413(1-2):237-44. doi:10.1016/j.ijpharm.2011.04.034.

2. Alhnan MA, Murdan S, Basit AW. Encapsulation of poorly soluble basic drugs into enteric microparticles: a novel approach to enhance their oral bioavailability. Int J Pharm. 2011;416(1):5560. doi:10.1016/j.ijpharm.2011.05.079.

3. Russell TL, Berardi RR, Barnett JL, O'Sullivan TL, Wagner JG, Dressman JB. pH-related changes in the absorption of dipyridamole in the elderly. Pharm Res. 1994;11(1):136-43.

4. Chin TW, Loeb M, Fong IW. Effects of an acidic beverage (CocaCola) on absorption of ketoconazole. Antimicrob Agents Chemother. 1995;39(8):1671-5.

5. Dai WG, Dong LC, Shi XF, Nguyen J, Evans J, Xu YD, et al. Evaluation of drug precipitation of solubility-enhancing liquid formulations using milligram quantities of a new molecular entity (NME). J Pharm Sci. 2007;96(11):2957-69. doi:10.1002/Jps.20886.

6. Galia E, Nicolaides E, Horter D, Lobenberg R, Reppas C, Dressman JB. Evaluation of various dissolution media for predicting in vivo performance of class I and II drugs. Pharm Res. 1998;15(5):698-705. doi:10.1023/A:1011910801212.

7. Kendall RA, Alhnan MA, Nilkumhang S, Murdan S, Basit AW. Fabrication and in vivo evaluation of highly $\mathrm{pH}$-responsive acrylic microparticles for targeted gastrointestinal delivery. Eur J Pharm Sci. 2009;37(3-4):284-90. doi:10.1016/j.ejps.2009.02.015.

8. Mathias NR, Xu Y, Patel D, Grass M, Caldwell B, Jager C, et al. Assessing the risk of $\mathrm{pH}$-dependent absorption for new molecular entities: a novel in vitro dissolution test, physicochemical analysis, and risk assessment strategy. Mol Pharm. 2013;10(11):4063-73. doi:10.1021/Mp400426f.

9. Klein S. The use of biorelevant dissolution media to forecast the in vivo performance of a drug. AAPS J. 2010;12(3):397-406. doi:10.1208/s12248-010-9203-3.

10. Parrott N, Lukacova V, Fraczkiewicz G, Bolger MB. Predicting pharmacokinetics of drugs using physiologically based modeling — application to food effects. AAPS J. 2009;11(1):4553. doi:10.1208/s12248-008-9079-7.

11. Gu CH, Rao D, Gandhi RB, Hilden J, Raghavan K. Using a novel multicompartment dissolution system to predict the effect of gastric 
$\mathrm{pH}$ on the oral absorption of weak bases with poor intrinsic solubility. J Pharm Sci. 2005;94(1):199-208. doi:10.1002/jps.20242.

12. Psachoulias D, Vertzoni M, Butler J, Busby D, Symillides M, Dressman J, et al. An in vitro methodology for forecasting luminal concentrations and precipitation of highly permeable lipophilic weak bases in the fasted upper small intestine. Pharm Res. 2012;29(12):3486-98. doi:10.1007/s11095-012-0844-z.

13. Taupitz T, Dressman JB, Klein S. In vitro tools for evaluating novel dosage forms of poorly soluble, weakly basic drugs: case example ketoconazole. J Pharm Sci. 2013;102(10):3645-52. doi:10.1002/Jps.23666.

14. Ham AS, Lustig W, Yang L, Boczar A, Buckheit KW, Buckheit RW. In vitro and ex vivo evaluations on transdermal delivery of the HIV inhibitor IQP-0410. PLoS One. 2013;8(9):e75306. doi:10.1371/journal.pone.0075306.

15. Mahayni H, Rekhi GS, Uppoor RS, Marroum P, Hussain AS, Augsburger LL, et al. Evaluation of "external" predictability of an in vitro-in vivo correlation for an extended-release formulation containing metoprolol tartrate. J Pharm Sci. 2000;89(10):1354-61. doi:10.1002/1520-6017(200010)89:10<1354::Aid-Jps13>3.0.Co;2-P.

16. Costa P, Sousa Lobo JM. Influence of dissolution medium agitation on release profiles of sustained-release tablets. Drug Dev Ind Pharm. 2001;27(8):811-7. doi:10.1081/DDC-100107244.

17. Bashir S, Nazir I, Khan H, Alamgeer, Asad M, ul Hassnain F, et al. Formulation and in vitro evaluation of nateglinide microspheres using HPMC and carbopol-940 polymers by ionic gelation method. Pak J Pharm Sci. 2013;26(6):1229-35.

18. Sievens-Figueroa L, Pandya N, Bhakay A, Keyvan G, MichniakKohn B, Bilgili E, et al. Using USP I and USP IV for discriminating dissolution rates of nano- and microparticle-loaded pharmaceutical strip-films. Aaps Pharmscitech. 2012;13(4):1473-82. doi:10.1208/s12249-012-9875-3.

19. Susarla R, Sievens-Figueroa L, Bhakay A, Shen YY, Jerez-Rozo JI, Engen W, et al. Fast drying of biocompatible polymer films loaded with poorly water-soluble drug nano-particles via low temperature forced convection. Int J Pharm. 2013;455(1-2):93103. doi:10.1016/j.ijpharm.2013.07.051.

20. Cora LA, Romeiro FG, Americo MF, Oliveira RB, Baffa O, Stelzer M, et al. Gastrointestinal transit and disintegration of enteric coated magnetic tablets assessed by ac biosusceptometry. Eur J Pharm Sci. 2006;27(1):1-8. doi:10.1016/j.ejps.2005.08.009.

21. Mitra F, Chowdhury S, Shelley M, Williams G. A feasibility study of transdermal buprenorphine versus transdermal fentanyl in the long-term management of persistent non-cancer pain. Pain Med. 2013;14(1):75-83. doi:10.1111/pme.12011.

22. Gentilcore D, Hausken T, Horowitz M, Jones KL. Measurements of gastric emptying of low- and high-nutrient liquids using 3D ultrasonography and scintigraphy in healthy subjects. Neurogastroenterol Motil. 2006;18(12):1062-8. doi:10.1111/ j.1365-2982.2006.00830.x.

23. Schmitz A, Kellenberger CJ, Liamlahi R, Studhalter M, Weiss M. Gastric emptying after overnight fasting and clear fluid intake: a prospective investigation using serial magnetic resonance imaging in healthy children. Br J Anaesth. 2011;107(3):425-9. doi:10.1093/ bja/aer167.

24. Paton DM, Webster DR. Clinical pharmacokinetics of H1receptor antagonists (the antihistamines). Clin Pharmacokinet. 1985;10(6):477-97.

25. Alhnan MA, Cosi D, Murdan S, Basit AW. Inhibiting the gastric burst release of drugs from enteric microparticles: the influence of drug molecular mass and solubility. J Pharm Sci. 2010;99(11):4576-83. doi:10.1002/jps.22174.

26. Heigoldt U, Sommer F, Daniels R, Wagner KG. Predicting in vivo absorption behavior of oral modified release dosage forms containing $\mathrm{pH}$-dependent poorly soluble drugs using a novel $\mathrm{pH}$ adjusted biphasic in vitro dissolution test. Eur J Pharm Biopharm. 2010;76(1):105-11. doi:10.1016/j.ejpb.2010.05.006.

27. Wennergren B, Lindberg J, Nicklasson M, Nilsson G, Nyberg G, Ahlgren $\mathrm{R}$, et al. A collaborative in vitro dissolution study-comparing the flow-through method with the USP paddle method using USP prednisone calibrator tablets. Int J Pharm. 1989;53(1):35-41. doi:10.1016/0378-5173(89)90358-X.

28. Kamba M, Seta Y, Takeda N, Hamaura T, Kusai A, Nakane H, et al. Measurement of agitation force in dissolution test and mechanical destructive force in disintegration test. Int J Pharm. 2003;250(1):99-109. doi:10.1016/S0378-5173(02)00535-5.

29. Wu Y, Ghaly ES. Effect of hydrodynamic environment on tablet dissolution using flow-through dissolution apparatus. P R Health Sci J. 2006;25(1):75-83. 